\title{
Elevation of Transforming Growth Factor $\beta 1$ mRNA Level in ES-D3 Mouse Embryonic Stem Cells Cocultured with Balb/c3T3 A31 Fibroblasts
}

\author{
Ken-ichi Katsube and Nobuyoshi Shimizu* \\ Department of Molecular Biology, Keio University School of Medicine, 35 Shinanomachi, Shinjuku-ku, Tokyo \\ 160, Japan
}

Key words: transforming growth factor $\beta 1 /$ embryonic stem cells/ Balb/c3T3/blastocyst/nonradioisotope in situ hybridization

\begin{abstract}
$A B S T R A C T$. Embryonic stem (ES) cells are a pluripotent cell line derived from the inner cell mass of the mouse blastocyst. The mRNA levels of several growth-related genes were examined in ES cells by Northern blot analysis under several different growth conditions. In a coculture of ES cells with the mouse fibroblast cell line, Balb/c3T3 A31, the expression level of transforming growth factor $\beta 1$ (TGF- $\beta 1$ ) mRNA was elevated for 1 to 3 days. In a coculture of ES cells with primary embryonic fibroblasts, only slight accumulation of TGF- $\beta 1$ mRNA was observed for 6 to $24 \mathrm{~h}$ and soon attenuated. In situ hybridization analysis revealed that TGF- $\beta 1$ transcripts accumulated first in the masses of ES cells and subsequently in Balb/c3T3 A31 cells adjacent to ES cells' masses. The ability of ES cells to induce TGF- $\beta 1$ in Balb/c3T3 A31 cells was not mediated by soluble factors and was lost upon differentiation. ES cells on primary embryonic fibroblasts grew in undifferentiated form, but those on Balb/c3T3 A31 cells stopped growing and formed embryoid cystic bodies. We suggest that TGF- $\beta 1$ mRNA induction in a coculture is triggered by an interaction between differentiating ES cells and Balb/c3T3 A31, and that this activity is limited to undifferentiated ES cells.
\end{abstract}

Embryonic stem (ES) cells were derived from the inner cell mass of the mouse blastocyst and established on a feeder layer of primary embryonic fibroblasts (4). ES cells can be maintained in undifferentiated form on the feeder layer, but without feeder they differentiate into all three germ layers including keratinocytes, nerve cells, myocardium, yolk sac endodermal cells and blood stem cells. Final differentiation represents embryoid cystic bodies in vitro after about 3 weeks (2).

Transforming growth factor $\beta$ (TGF- $\beta$ ) was identified as a polypeptide growth factor that can transform normal rat kidney (NRK) cells (13). Although this factor was first purified from the conditioned media of virally transformed cells, it is now known to be secreted by almost any type of tissues and cells. The TGF- $\beta 1$ gene expression is strong in the bone, cartilage and mammary glands during mouse development and in the placenta (15). These results suggest that TGF- $\beta 1$ is involved in the growth and differentiation of mesodermal tissues in organogenesis, although direct evidence has not yet been shown.

We observed that ES cells grew well on a feeder layer of primary embryonic fibroblasts, but ES cells plated on the mouse fibroblast cell line, Balb/c3T3 A31, stopped growing. Thus, precise analysis of the growth

\footnotetext{
* To whom correspondence should be addressed.
}

factor's role in the growth and development of ES cells was thought to be important not only for understanding basic physiology but also for improving genetic manipulation of ES cells. To elucidate the relationship between the growth of ES cells and growth-related genes, we have carried out Northern blot analysis and observed that the TGF- $\beta 1$ mRNA level in ES cells was elevated transiently when they were cocultured with Balb/c3T3 A31 cells, but was suppressed when they were cocultured with primary embryonic fibroblasts. We performed several experiments to analyze the mechanisms of TGF- $\beta 1$ mRNA induction in the coculture.

\section{MATERIALS AND METHODS}

Cell lines and culture techniques. ES-D3, one of the ES cell lines, was supplied by Dr. R. Kemler. ES-D3 was cultured on a feeder layer of primary embryonic fibroblasts in Dulbecco's modified Eagle's medium (DMEM) with 20\% fetal calf serum (FCS) and passaged every other day with $1: 3$ dilution. Balb/c3T3 A31 and primary embryonic fibroblasts were cultured in DMEM with 10\% FCS. A coculture of ES-D3 with fibroblasts was also maintained in DMEM with $10 \% \mathrm{FCS}$.

Embryonic fibroblasts were dissociated from day-14 embryo of the STD/ddY mouse by trypsinization and cultured in DMEM 10\% FCS for several days (2). Embryonic fibroblasts for maintenance of ES-D3 were treated with $30 \mu \mathrm{g} / \mathrm{ml}$ mitomy- 
cin- $\mathrm{C}$ for $2 \mathrm{~h}$ one day before inoculation of ES cells. Human TGF- $\beta 1$ and rabbit anti-TGF- $\beta 1$ antiserum were provided by Dr. R. Hirai.

$R N A$ isolation and Northern blot analysis. RNA was extracted from each culture growing on $15-\mathrm{cm}$ dishes. Feeder layer fibroblasts were cultivated to a semiconfluent stage (about $1 \times 10^{7}$ cells per dish) to which $3 \times 10^{6}$ ES-D3 cells were inoculated. Cells were washed once with phosphate-buffered saline (PBS) containing $0.02 \%$ EDTA and lysed on the dish with $\mathrm{LiCl}$ solution ( $3 \mathrm{M} \mathrm{LiCl}, 6 \mathrm{M}$ urea, $50 \mathrm{mM}$ Tris- $\mathrm{HCl}, \mathrm{pH}$ 7.4, 5 mM EDTA, 0.1 M 2-mercaptoethanol, 0.1\% Sarkosyl). Cell lysate was sonicated for $30 \mathrm{sec}$ and kept overnight on ice. RNA was precipitated by centrifugation for $20 \mathrm{~min}$ at $10000 \times \mathrm{g}$. RNA pellets were dissolved in Tris-EDTA-SDS buffer (10 mM Tris-HCl, pH 7.4, $1 \mathrm{mM}$ EDTA, 0.5\% SDS), and impurities were excluded by butanol-chloroform $(1: 4)$.

Total RNA $(20 \mu \mathrm{g})$ was electrophoresed on $1 \%$ formaldehyde agarose gel. RNA was transferred to a Gene Screen Plus filter (DuPont) and hybridized to ${ }^{32} \mathrm{P}$-labeled probes. Hybridization and washing were carried out according to the manufacturer's manual. Mouse TGF- $\beta 1$ cDNA clone, $\mathrm{p} \beta$-ms was provided by Dr. R. Derynck (3). Autoradiography was performed with Fuji RX X-ray film. In the case of dot blot hybridization, $5 \mu \mathrm{g}$ of total RNA was dotted to the Gene Screen Plus filter by means of a vacuum dot blotter (Bio-Rad). Hybridization was performed under the same conditions as Northern blot analysis.

In situ hybridization. Balb/c3T3 A31 cells were cultured on slide glasses for one day before inoculation of ES cells. After $24 \mathrm{~h}$ cocultivation, cells were fixed with freshly prepared $4 \%$ paraformaldehyde, dissolved in PBS and preserved at $4^{\circ} \mathrm{C}$. TGF- $\beta 1 \mathrm{cDNA}$ was labeled with digoxigenin-11-dUTP by means of a digoxigenin oligo-labeling kit (BoehringerMannheim). Each slide was covered with $100 \mu$ l hybridization buffer $[4 \times$ standard saline citrate (SSC: $15 \mathrm{mM}$ sodium citrate, $150 \mathrm{mM} \mathrm{NaCl}$ ), $50 \%$ formamide, Denhardt's solution, $5 \%$ dextran sulfate, $0.5 \mathrm{mg} / \mathrm{ml}$ salmon sperm DNA, and 0.25 $\mathrm{mg} / \mathrm{ml}$ yeast $\mathrm{tRNA}$ ] containing digoxigenin-labeled TGF- $\beta 1$ cDNA probe for $24 \mathrm{~h}$. Equal amounts of $\lambda$ phage DNA labeled with digoxigenin were used in control experiments. Slides were washed with $2 \times \mathrm{SSC}$ for $1 \mathrm{~h}$ and then with $0.5 \times \mathrm{SSC}$ for $30 \mathrm{~min}$ at $37^{\circ} \mathrm{C}$. Immunological color detection was performed using alkaline-phosphatase conjugated antidigoxigenin antibody and a color staining kit (BoehringerMannheim).

\section{RESULTS}

TGF- 1 I mRNA level in ES cells was elevated during cocultivation with fibroblast cell line. The growth of ES-D3 cells on Balb/c3T3 A31 cells was arrested in a few days, and the growth of ES-D3 cells on primary embryonic fibroblasts continued (Fig. 1). In a coculture with ES-D3, the feeder Balb/c3T3 A31 becameloosely attached, changed to a round shape and extended fine processes
(Fig. 1B). These morphological changes were transient and were restored a flat shape when the coculture was refed with fresh medium, indicating that the cells were viable although barely growing. This phenomenon occurred on A31 cells adjacent to ES cells' masses and spread out to A31 cells in the marginal area. ES cells on the feeder layer of Balb/c3T3 A31 formed embryoid cystic bodies in 2 days. After about one week, a reticular structure appeared (Fig. 1D) and the streaks contained ES cells and A31 cells. This structure resembles a hydatidiform mole, but further investigation is necessary to clarify its significance. To examine the relationship between the growth of ES-D3 and expression of growth-related genes in this stage, RNA was extracted from the coculture, and Northern dot blot analysis, was carried out using cDNA probes of epidermal growth factor (EGF), TGF $\alpha$, EGF receptor, TGF- $\beta 1$, c-erbB-2 and platelet-derived growth factor (PDGF) receptor $\beta$ chain (Fig. 2). We found that the TGF- $\beta 1 \mathrm{mRNA}$ level in a coculture of ES-D3 cells with Balb/c3T3 A31 cells was elevated during 1 to 2 days of cocultivation, and the mRNA level of other genes showed little change (Fig. 2 ). This transient elevation of TGF- $\beta 1 \mathrm{mRNA}$ expression was also observed in a coculture of ES-D3 cells with other fibroblast cell lines, Balb/c3T3 $3 \mathrm{~K}$ and NIH/3T3 (data not shown).

We next examined the change in amounts of TGF- $\beta 1$ mRNA by Northern blot hybridization (Fig. 3). TGF$\beta 1 \mathrm{mRNA}$ accumulation in a coculture of ES-D3 with Balb/c3T3 A31 was clearly observed for 1 to 3 days after inoculation of ES cells. Accumulation was observed $3 \mathrm{~h}$ after inoculation, remaining at a maximal level for 2 to 3 days. Then the TGF- $\beta 1 \mathrm{mRNA}$ level was reduced to the same level as the Balb/c3T3 A31 cells after 4 days. TGF- $\beta 1 \mathrm{mRNA}$ accumulation in the coculture of ES-D3 with primary embryonic fibroblasts was observed for 6 to $24 \mathrm{~h}$ but only in low levels. After that, the TGF- $\beta 1$ mRNA level was reduced.

The TGF- $\beta 1$ mRNA level in ES-D3 cells without the feeder layer was very low. TGF- $\beta 1$ mRNA was accumulated gradually in both Balb/c3T3 A31 cells and the primary embryonic fibroblasts, but the mRNA level was low.

TGF- $\beta 1$ mRNA accumulation was first observed in ES cells' masses. To clarify the localization of TGF$\beta 1 \mathrm{mRNA}$ in a coculture of ES-D3 with Balb/c3T3 A31 cells, in situ hybridization was carried out using a TGF$\beta 1$ cDNA probe labeled with digoxigenin (Fig. 4). TGF$\beta 1$ transcripts were clearly detectable in the masses of ES-D3 cells 1 day after inoculation but were almost reduced 2 days later. TGF- $\beta 1$ transcripts in Balb/c3T3 A31 cells adjacent to ES cells' masses could be observed after 2 days. Limited localization of TGF- $\beta 1$ transcripts suggests that TGF- $\beta 1$ mRNA accumulation in Balb/ c3T3 A31 cells may be stimulated by interaction with 

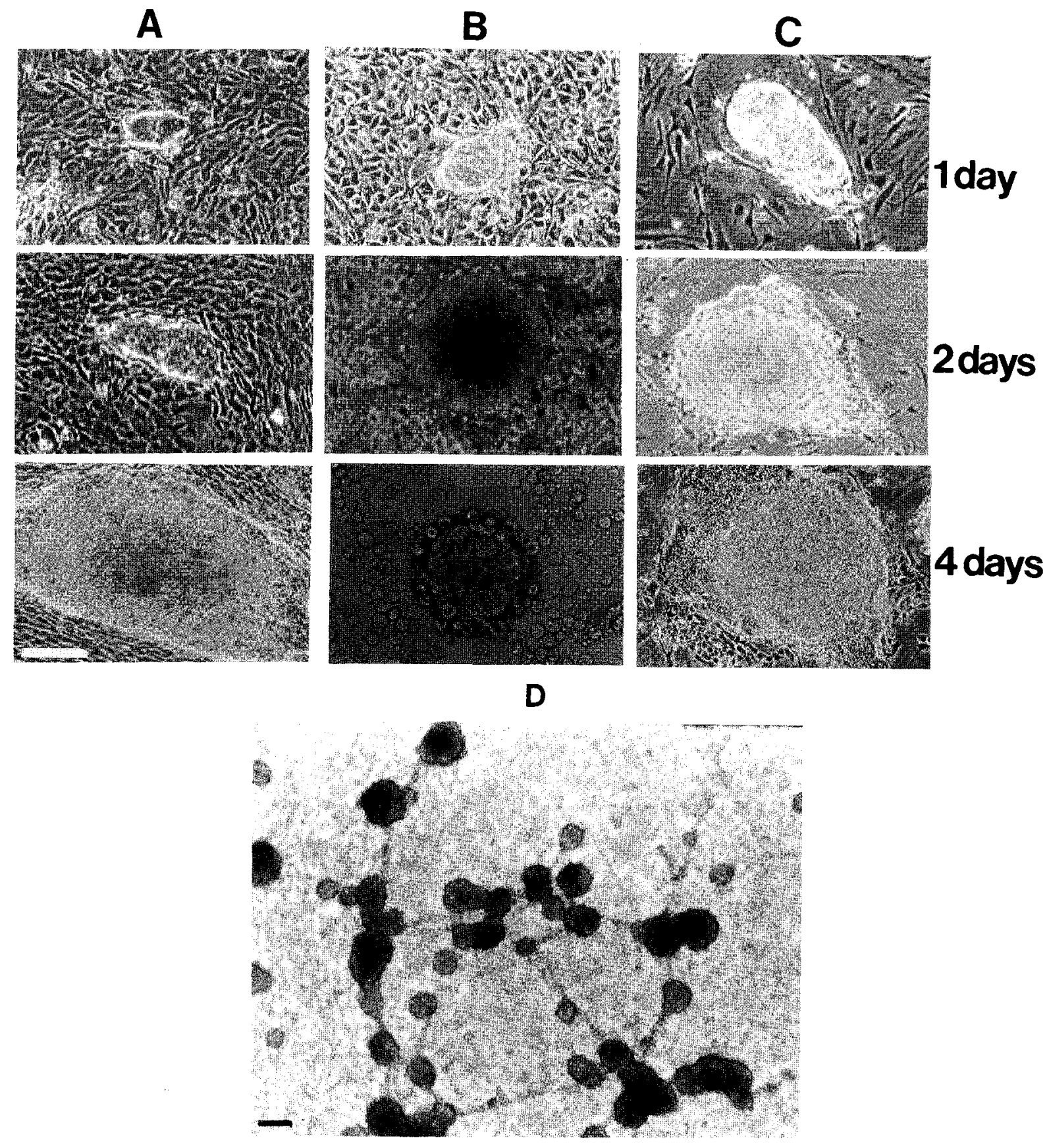

Fig. 1. Morphological change of ES-D3 cells. A: cultured on feeder layer of primary embryonic fibroblasts, B: cultured on feeder layer of Balb/c3T3 A31, C: cultured without feeder layer, D: cultured on feeder layer of Balb/c3T3 A31 for a week. Scale bar: $50 \mu \mathrm{m}$.

ES-D3 cells.

TGF- $\beta 1$ mRNA accumulation was not induced by soluble factors in medium. To determine whether TGF- $\beta 1$ mRNA accumulation is due to soluble factors in media, we treated ES-D3 cells with TGF- $\beta 1$, which was reported to induce TGF- $\beta 1$ gene expression (7). $\mathrm{Hu}$ man TGF- $\beta 1(5 \mathrm{ng} / \mathrm{ml})$ was added to a medium of ES-
D3 for $2 \mathrm{~h}$, and the TGF- $\beta 1$ mRNA level was examined. However, there was no significant change in the TGF$\beta 1 \mathrm{mRNA}$ level (Fig. 5). Addition of anti-TGF- $\beta 1$ antiserum to a coculture for $24 \mathrm{~h}$ could not block TGF- $\beta 1$ mRNA accumulation. These results suggest that TGF$\beta 1$ itself plays little role in TGF- $\beta 1$ mRNA accumulation in this coculture. 


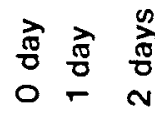

$$
\begin{aligned}
& \text { A A A } \\
& \text { B B } B \\
& \text { C C C } \\
& \text { D D } \\
& \text { E E }
\end{aligned}
$$
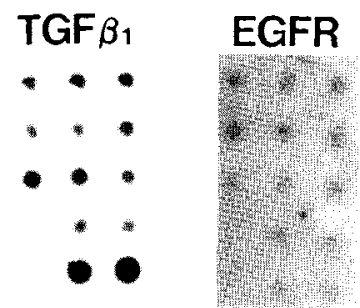

EGF

c-erbB-2

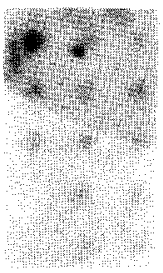

TGF $\alpha$
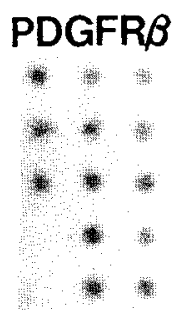

Fig. 2. Change in mRNA levels of growth-related genes in coculture of ES-D3 with fibroblasts. A: primary embryonic fibroblasts, B: Balb/c3T3 A31, C: ES-D3 without feeder layer, D: coculture of ES-D3 with primary embryonic fibroblasts, E: coculture of ES-D3 with Balb/c3T3 A31.

Fig. 3. 3-1: Time course of TGF- $\beta 1$ mRNA expression during cocultivation of ES-D3 with fibroblasts. A: Balb/c3T3 A31, B: primary embryonic fibroblasts, C: ES-D3 without feeder layer, D: coculture of ES-D3 with Balb/c3T3 A31, E: coculture of ES-D3 with primary embryonic fibroblasts. 3-2: Relative intensity of Northern blot hybridization. Signal intensity was quantified by laser densitometer (LKB 2202 Ultroscan), and relative intensity was determined by comparison with the intensity of Balb/c3T3 A31 (0 day). Open circle: Balb/c3T3 A31, open triangle: primary embryonic fibroblasts, open square: ES-D3 without feeder layer, closed circle: coculture of ES-D3 with Balb/c3T3 A31, closed triangle: coculture of ES-D3 with primary embryonic fibroblasts.
A
D

01234 days

1234 days

$361224 \mathrm{hr}$

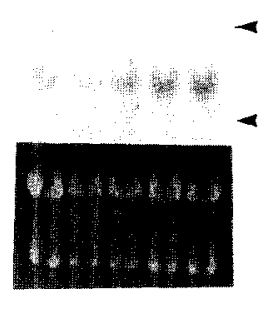

B

01234 days

$E$

1234 days

$361224 \mathrm{hr}$

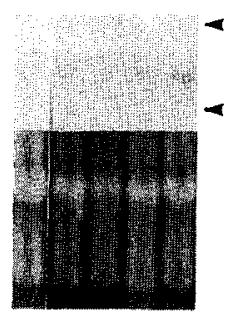

$-28 \mathrm{~S}$

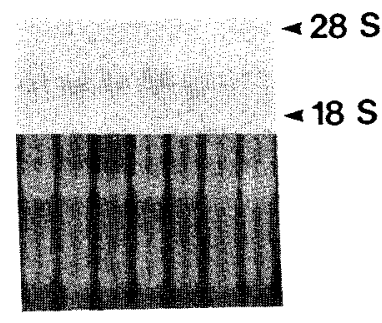

C

01234 days

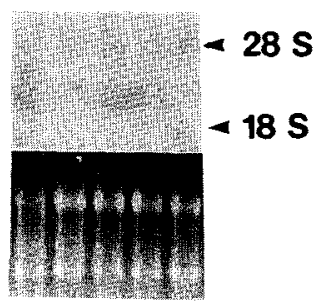

Fig. 3-1.

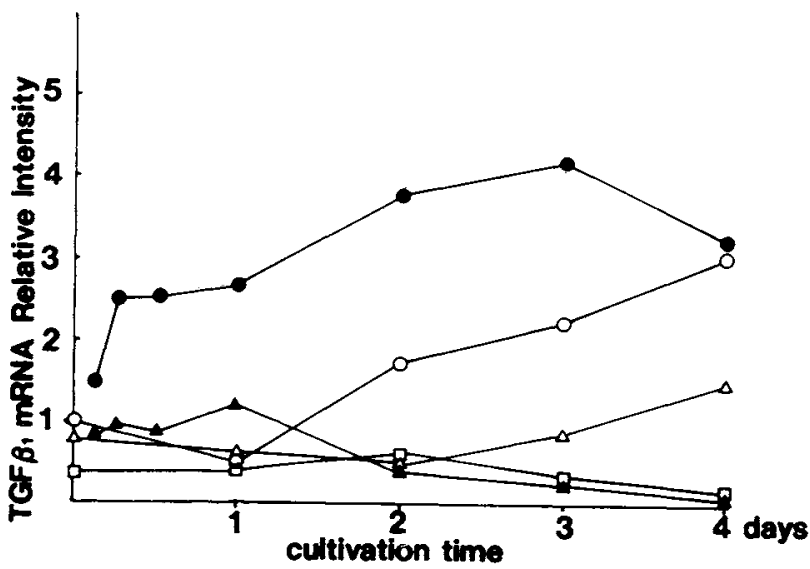

Fig. 3-2. 


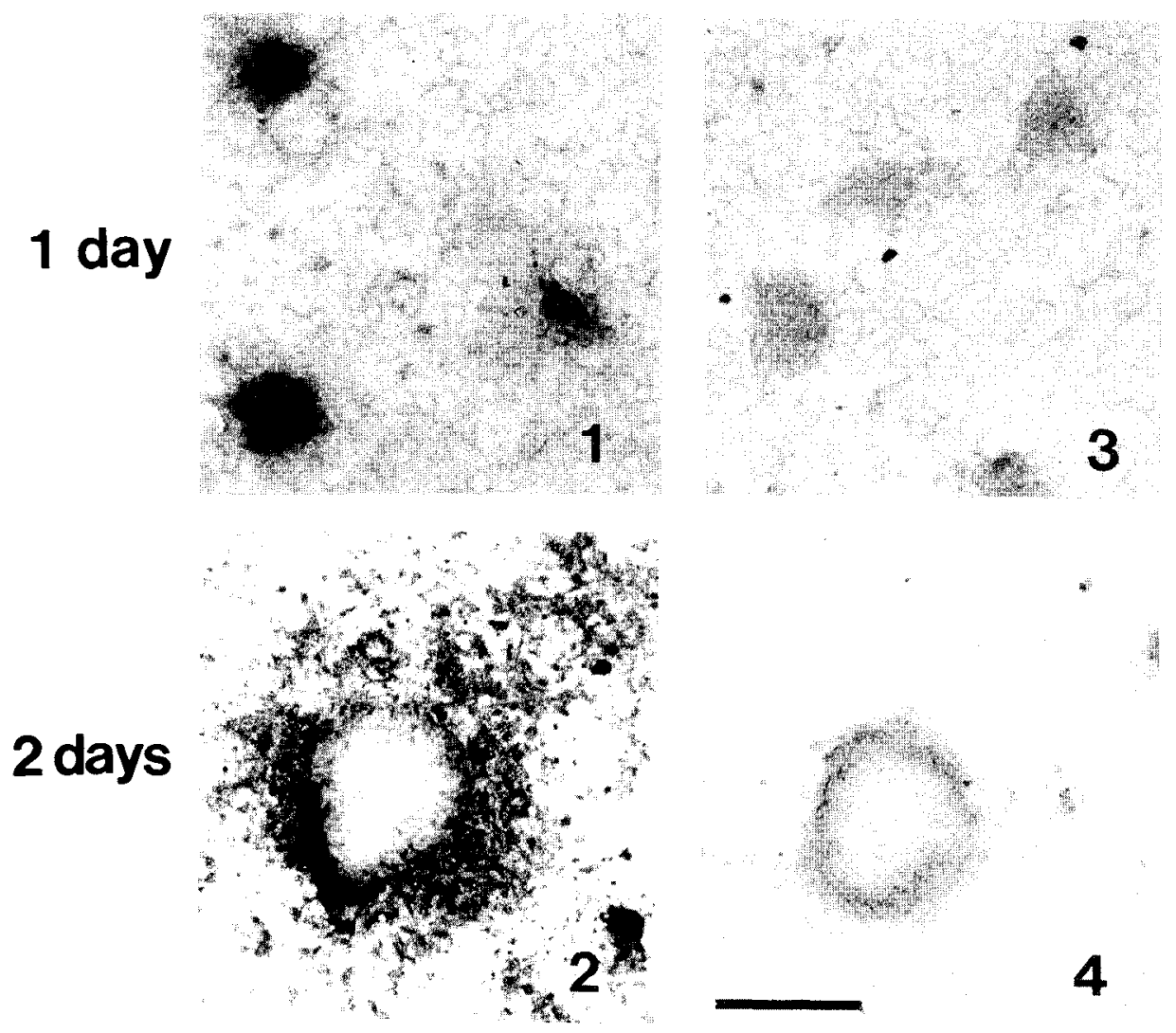

Fig. 4. In situ hybridization of ES cells during cocultivation. ES cells were inoculated to feeder layer of Balb/c3T3 A31 and cocultured for 1 day or 2 days. 1 and 2: TGF- $\beta 1$ cDNA, 3 and 4: control $\lambda$ phage DNA. Scale bar: $100 \mu \mathrm{m}$.

Retinoic acid was reported to induce TGF- $\beta 1$ and $-\beta 2$ mRNA expression in keratinocytes (5) but its addition $\left(1 \times 10^{-6} \mathrm{M}\right)$ to ES-D3 did not produce much of an effect on TGF- $\beta 1$ mRNA accumulation. We also examined the conditioned medium of a 1-day coculture of ES-D3 with Balb/c3T3 A31 to determine if any unknown TGF- $\beta 1$ mRNA-inducing factors exist. But addition of the conditioned medium to ES-D3 also had no effect. These results suggest that soluble factors have little effect on TGF- $\beta 1$ mRNA accumulation in the coculture.

Differentiated ES cells lost their ability to induce TGF- 1 I mRNA accumulation. We examined differentiated ES-D3 to determine whether they can induce TGF- $\beta 1$ mRNA accumulation in a coculture. ES cells without a feeder layer differentiate gradually to three germ layers and lose their pluripotency (2). We inoculated ES-D3 cells, cultured without a feeder layer for several days, on Balb/c3T3 A31. Total cells of the coculture were harvested 1 day after inoculation. The coculture in which ES-D3 was cultured for 1 day without a feeder layer showed the highest accumulation of TGF$\beta 1$ mRNA (Fig. 6). TGF- $\beta 1$ mRNA accumulation was gradually lost in the coculture in which ES-D3 cells were cultured without a feeder layer for a longer period. Thus, it is important to inoculate ES-D3 prior to differentiation or at least in the early differentiation stage to induce TGF- $\beta 1 \mathrm{mRNA}$ accumulation in the coculture.

Blastocyst plated on Balb/c3T3 A3I began to express TGF- 11 mRNA. We collected blastocysts from pregnant C57 mice and plated them on Balb/c3T3 A31 cells to determine whether TGF- $\beta 1$ mRNA accumulation could be observed. Blastocysts were plated on the feeder layer for 2 days to encourage trophectoderm outgrowth and the inner cell mass differentiation. In situ hybridization using TGF- $\beta 1$ cDNA probe labeled with digoxigenin revealed that primitive ectoderm-like cells began to express TGF- $\beta 1$ mRNA (Fig. 7). In addition, some fibroblasts which were adjacent to the trophectoderm seemed to elevate TGF- $\beta 1 \mathrm{mRNA}$ level. Blastocysts on Balb/c3T3 A31 cells seem to have the potential for TGF- $\beta 1$ mRNA accumulation. 


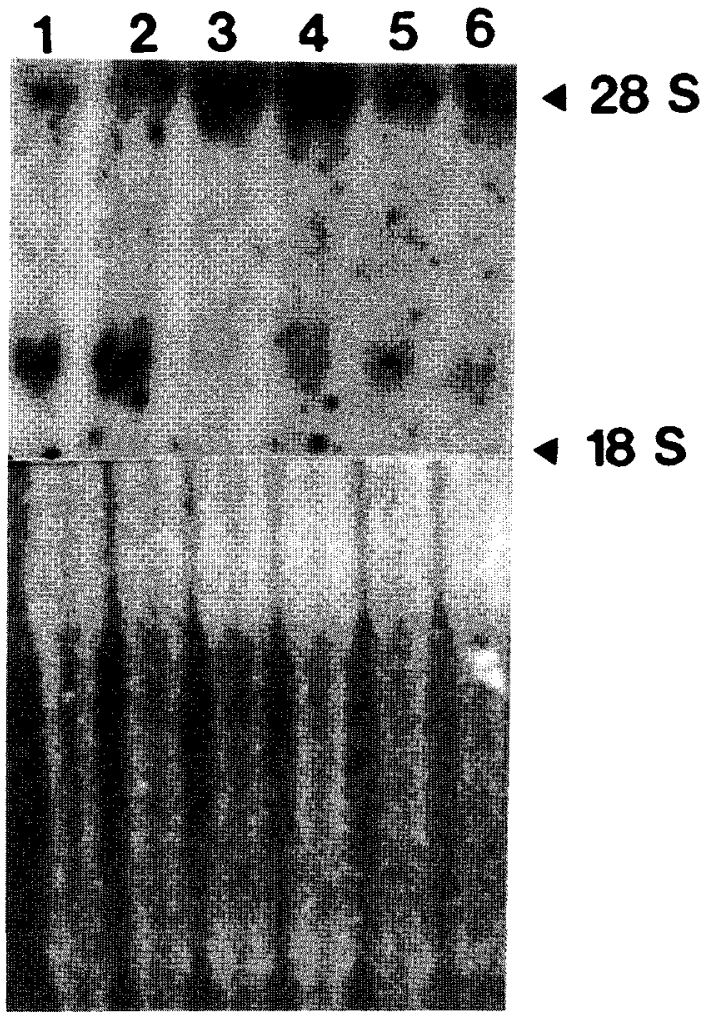

Fig. 5. Effect of several factors on TGF- $\beta 1$ mRNA accumulation in ES cells and of anti-TGF- $\beta 1$ antiserum on coculture of ES cells with Balb/c3T3 A31. Lane 1: coculture of ES-D3 with Balb/c3T3 A31, lane 2: coculture of ES-D3 with Balb/c3T3 A31 treated with rabbit anti-TGF- $\beta 1$ antiserum for 1 day, lane 3: ES-D3 with no treatment, lane 4: ES-D3 treated with retinoic acid $\left(1 \times 10^{-6} \mathrm{M}\right)$ for 2 days, lane 5: ES-D3 treated for $2 \mathrm{~h}$ with TGF- $\beta 1(5 \mathrm{ng} / \mathrm{ml})$ and lane 6: ES-D3 treated for $2 \mathrm{~h}$ with conditioned medium of coculture of ES-D3 with Balb/c3T3 A31 for 1 day.
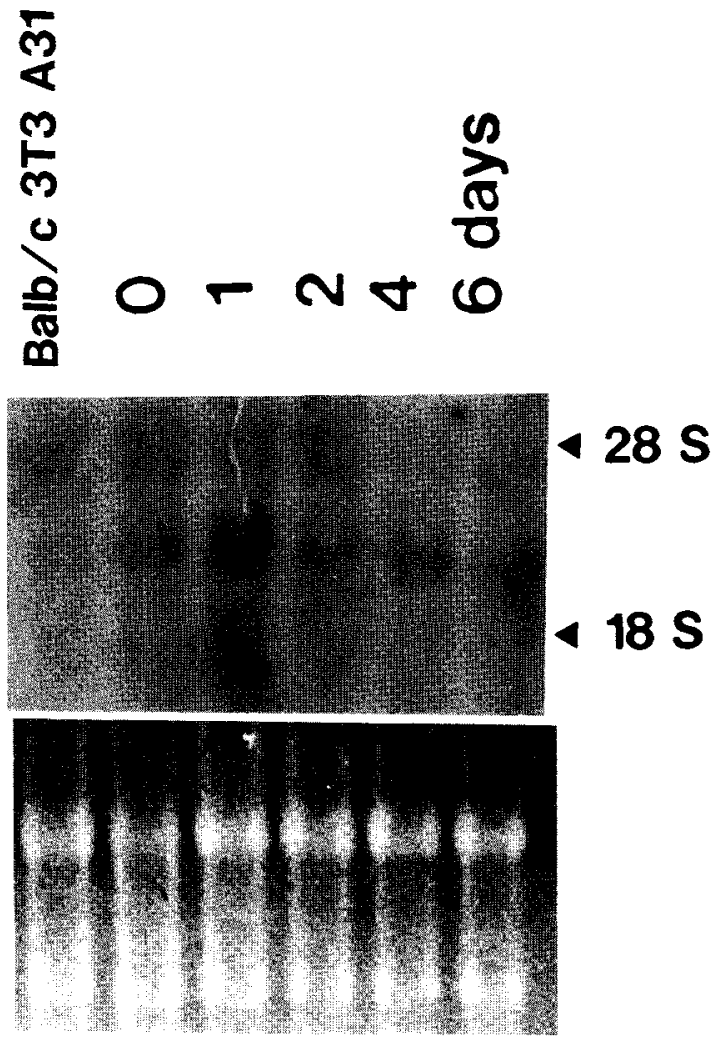

Fig. 6. TGF- $\beta 1$ mRNA-inducing activity of differentiated ES-D3 in coculture with Balb/c3T3 A31. ES cells were cultured for several days without feeder layer and inoculated to the feeder layer of Balb/c3T3 A31. Total RNA was extracted after 1 day cocultivation.

\section{DISCUSSION}

ES cells on a feeder layer of primary embryonic fibroblasts grew continuously in undifferentiated form. But ES cells on Balb/c3T3 A31 soon arrested to grow and form embryoid cystic bodies. We carried out Northern

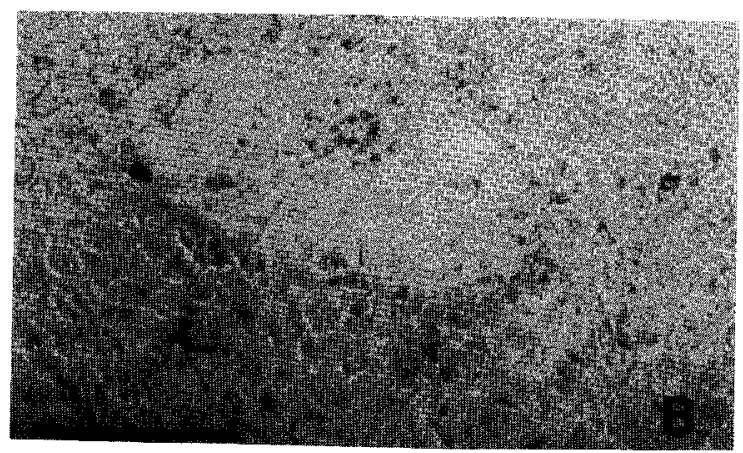

Fig. 7. (A) In situ hybridization of mouse blastocyst plated on feeder layer of Balb/c3T3 A31 by TGF- $\beta 1$ cDNA probes. Arrowheads indicate primitive ectoderm-like cells. (B) Phase-contrast photomicrograph of same area before fixation. Scale bar: $100 \mu \mathrm{m}$. 
blot analysis to examine the change in transcription levels of several growth-related genes. Significant change was found only in TGF- $\beta 1$. The TGF- $\beta 1 \mathrm{mRNA}$ level in a coculture of ES-D3 with Balb/c3T3 A31 was elevated for 1 to 3 days and reduced after 4 days. The TGF- $\beta 1 \mathrm{mRNA}$ level was attenuated in a coculture of ES-D3 with primary embryonic fibroblasts. The TGF$\beta 1$ mRNA level in ES-D3 cells cultured without a feeder layer was low and showed no significant change. Transient elevation of TGF- $\beta 1 \mathrm{mRNA}$ expression was observed in a coculture of ES-D3 cells with other fibroblast cell lines, Balb/c3T3 $3 \mathrm{~K}$ and NIH/3T3.

In situ hybridization was performed to determine the localization of TGF- $\beta 1$ mRNA accumulation in the coculture of ES-D3 cells with Balb/c3T3 A31 cells. TGF- $\beta 1$ mRNA accumulation was observed in the masses of ES-D3 1 day after inoculation. This accumulation disappeared after 2 days, and in Balb/c3T3 A31 cells adjacent to the masses of ES-D3, subsequently, the TGF$\beta 1 \mathrm{mRNA}$ level was elevated. These results indicate that ES cells seem responsible for the early stage of TGF- $\beta 1$ mRNA accumulation, and Balb/c3T3 A31 cells appear to be responsible for the later stage.

Addition of TGF- $\beta 1$ to the ES-D3 culture induced no accumulation of TGF- $\beta 1$ mRNA, and addition of antiTGF- $\beta 1$ antiserum to the coculture of ES-D3 with Balb /c3T3 A31 did not block TGF- $\beta 1$ mRNA accumulation. These results suggest that TGF- $\beta 1$ itself plays little role in TGF- $\beta 1$ mRNA induction in the coculture. Treatment with retinoic acid or conditioned medium of the coculture did not elevate the TGF- $\beta 1$ mRNA level in ES-D3. Considering these data and the pattern of TGF- $\beta 1$ mRNA distribution, the TGF- $\beta 1$-inducing signal in a coculture does not seem to be a soluble factor, but perhaps is mediated via cell-cell interaction between ES cells and Balb/c3T3 A31 cells.

ES cells cultured without a feeder layer (standard condition for differentiation) gradually differentiated and formed embryoid cystic bodies after about 3 weeks (2). These differentiated ES-D3 cells lost their ability to induce TGF- $\beta 1 \mathrm{mRNA}$ accumulation. The initiation signal for TGF- $\beta 1$ mRNA accumulation has not yet been determined, but it seems to depend on spontaneous differentiation of ES cells and their contact with Balb/ c3T3 A31 cells. ES-D3 on Balb/c3T3 A31 exhibited accelerated morphological change in forming embryoid cystic bodies as compared with those cultured without feeder cells (Fig. 1). Blastocysts plated on Balb/c3T3 A31 began to express TGF- $\beta 1$ mRNA preferentially in primitive ectoderm-like cells, and marginal fibroblasts began to express TGF- $\beta 1 \mathrm{mRNA}$. Considering that ES cells were established from the inner cell mass of blastocysts, the TGF- $\beta 1$-inducing ability of ES cells may reflect an original characteristic of the inner cell mass in blastocysts.
It has previously been reported that TGF- $\beta 1$ mRNA levels in embryonal carcinoma cell lines and ES cells were low and no particular change was found with retinoic acid treatment (6). A minute amount of TGF- $\beta 1$ mRNA was detected in the mouse blastocyst at the preimplantation stage (days 2 to 3 ) by reverse transcription-polymerase chain reaction (RT-PCR), but no significant change was observed (12). TGF- $\beta 1 \mathrm{mRNA}$ levels in ES cells on feeder cells were not tested in these studies. By our results, it is necessary to culture ES cells or blastocysts with feeder fibroblasts to induce TGF- $\beta 1$ mRNA accumulation.

The TGF- $\beta 1$ mRNA level was elevated in epithelial cells on the uterine wall in the preimplantation stage, and it elevated strongly and diffusely in decidual tissue of an embryo in the implantation stage (days 4 to 5 ) (14). Therefore, TGF- $\beta 1$ was postulated to play important roles in the implantation process (growth stimulation of uterine epithelial cells, immunosuppression for placentation). It is difficult to collect sufficient blastocysts for molecular level analysis, and the coculture of ES cells with fibroblast cell lines provides a model system for this analysis.

TGF- $\beta 2$ has been reported to be expressed in ES cells and several totipotent embryonal carcinoma cell lines when differentiated (10). TGF- $\beta 2$ was also detected in the mouse blastocyst when transferred to a feeder layer of fibroblast cell lines in vitro. The importance of TGF$\beta 2$ and TGF- $\beta 3$ in early embryogenesis has also been demonstrated $(9,11)$. The roles of TGF- $\beta 1$ in the late developmental stage $(8,16)$, involving mammary glands, bone and heart formation, have been discussed. But its role in the early developmental stage is not clear. Gene expression of TGF- $\beta 2$ and TGF- $\beta 3$ requires TGF- $\beta 1$, and complex coordination of gene expression among the TGF- $\beta$ gene family has been postulated (1). We suppose that TGF- $\beta 1$ may promote blastocyst implantation in cooperation with other TGF- $\beta$ family. Further studies using a coculture of ES cells with a fibroblast cell line may elucidate this regulatory system.

Acknowledgments. This work was supported by a Grant-in-Aid from the Ministry of Education, Science and Culture, Japan. We thank Dr. Y. Hirabayashi for the supply of mouse blastocysts and Dr. S. Gamou and Dr. S. Minoshima for their critical comments on the manuscript. We also thank Ms. H. Harigai for her assistance in manuscript preparation.

\section{REFERENCES}

1. Bascom, C.C., Wolfshohl, J.R., Coffey, R.J., JR, Madisen, L., Webb, N.R., Purchio, A.R., Derynck, R., and Moses, H.L. (1989). Complex regulation of transforming growth factor $\beta 1, \beta 2$, and $\beta 3$ mRNA expression in mouse fibroblasts and keratinocytes by transforming growth factor $\beta 1$ and $\beta 2$. Mol. Cell. Biol., 9: 5508-5515. 
2. Doetschman, T.C., Eistetter, H., Katz, M., Schmdt, W., and KEMLER, R. (1985). The in vitro development of blastocyst-derived embryonic stem cells: formation of visceral yolk sac, blood islands and myocardium. J. Embryol. Exp. Morphol., 87: 27-45.

3. Derynck, R., JARetT, J.A., Chen, E.Y., and Goeddel, D.V. (1986). The Murine transforming growth factor- $\beta$ precursor. J. Biol. Chem., 261: 4377-4379.

4. Evans, M.J. and Kaufman, M.H. (1981). Establishment in culture of pluripotential cells from mouse embryos. Nature, 292: $154-156$

5. Glick, A.B., Flanders, K.C., Danielpour, D., Yuspa, S.H., and SPORN, M.B. (1989). Retinoic acid induces transforming growth factor- $\beta 2$ in cultured keratinocytes and mouse epidermis. Cell Regulation, 1: 87-97.

6. Heath, J.K., Smith, A.G., Wills, A.J., and Edwards, D.R. (1989). Growth and differentiation factors of embryonic stem cells. NATO ASI Series., vol. H26: 219-245.

7. KIM, S.-J., JeAng, K.-T., Glick, A.B., Sporn, M.B., and RoBerTs, A.B. (1989). Promoter sequences of the human transforming growth factor- $\beta 1$ gene responsive to transforming growth factor- $\beta 1$ autoinduction. J. Biol. Chem., 264: 70417045 .

8. LeHNeRT, S.A. and Akhurst, R.J. (1988). Embryonic expression pattern of TGF beta type-1 RNA suggests both paracrine and autocrine mechanisms of action. Development, 104: 263273.

9. Miller, D.A., Lee, A., Pelton, R.W., Chen, E.Y., Moses, H.L., and DERYNCK, R. (1989). Murine transforming growth factor- $\beta 2$ cDNA sequence and expression in adult tissues and embryos. Mol. Endocrinol., 3: 1108-1114.

10. Mummery, C.L., Slager, H., Kluijer, W., Feijen, A., Freund, E., Koornneef, I., and VAN Den EIJNDEN-VAN RAAIJ, A.J.M. (1990). Expression of transforming growth factor- $\beta 2$ during the differentiation of murine embryonal carcinoma and embryonic stem cells. Dev. Biol., 137: 161-170.

11. Pelton, R.W., Nomura, S., Moses, H.L., and Hogan, B.L.M. (1989). Expression of transforming growth factor beta 2 RNA during murine embryogenesis. Development, 106: 759-767.

12. RapPolee, D.A., Brenner, C.A., Schultz, R., Mark, D., and WERB, Z. (1989). Developmental expression of PDGF, TGF$\alpha$, and TGF- $\beta$ in preimplantation mouse embryos. Science, 241: 155-164.

13. Roberts, A.B., Anzano, M.A., Lamb, L.C., Smith, J.M., Frolik, C.A., Marquardt, H., Todaro, G.J., and Sporn, M.B. (1982). Isolation from murine sarcoma cells of novel transforming growth factors potentiated by EGF. Nature, 295: $417-419$.

14. Tamada, H., Mcmaster, M.T., Flanders, K.C., Andrews, G.K., and DEY, S.K. (1990). Cell type-specific expression of transforming growth factor- $\beta 1$ in the mouse uterus during the preimplantation period. Mol. Endocrinol., 4: 965-972.

15. Thompson, N.L., Flanders, K.C., SMith, J.M., ElLINGWorth, L.R., RoBerts, A.B., and SPORN, M.B. (1989). Expression of transforming growth factor- $\beta 1$ in specific cells and tissues of adult and neonatal mice. $J$. Cell Biol., 108: 661-669.

16. Wilcox, J.N. and Derynck, R. (1988). Developmental expression of transforming growth factors alpha and beta in mouse fetus. Mol. Cell. Biol., 8: 3415-3422.

(Received for publication, April 9, 1991

and in revised form, July 11, 1991) 